\title{
Short-term amelioration of soil properties and maize yield enhancement using animal wastes in degraded hydromorphic soils of Southeastern Nigeria
}

\author{
Okenmuo F. C. ${ }^{1^{*}}$, Odii O. U. ${ }^{2}$ and Okolo C. C. ${ }^{3}$ \\ ${ }^{1}$ Department of Environmental Management, Pan African University of Life and Earth Sciences, University of Ibadan, \\ Nigeria. \\ ${ }^{2}$ National Biotechnology Development Agency, Nigeria. \\ ${ }^{3}$ Department of Land Resources Management and Environmental Protection, Mekelle University, Ethiopia.
}

Received 19 March, 2018; Accepted 4 June, 2018

\begin{abstract}
Amending soil with animal wastes can be useful in food production as well as a means of waste disposal. It has been found to enhance physico-chemical properties and enhance yield. Poultry manure (PM), swine waste (SW), cow dung (CD), and sewage sludge (SS) were added to a hydromorphic ultisol (sandy loam, typic haplusult at the rate of 10 tha $^{-1}\left(12 \mathrm{kgplot}^{-1}\right)$ ). Maize hybrid (Oba super II) was used as test crop. Randomized Complete Block Design (RCBD) with four replications was used in laying the experiment. Data collected were analyzed using analysis of variance (ANOVA) and means were separated using Fishers' Least Significant Difference (F-LSD). Physical properties of soil influenced by animal wastes include bulk density, total porosity, hydraulic conductivity, gravimetric moisture contents, aggregate stability, and rheological characteristics. Amendments also enhanced soil organic matter, total nitrogen, available phosphorus, potassium, calcium, magnesium and sodium, $\mathrm{pH}$, exchangeable acidity, cation exchange capacity, and base saturation were all higher relative to the unamended plots. Productivity studies revealed that maize growth was significantly affected by amendments especially PM. This was observed in height, leaf area index and yield higher relative to the control. Generally, the increase followed the order $P M>S W>S S>C D$. Animal wastes especially from poultry sources are recommended for soil amelioration and for increased crop yield in the area.
\end{abstract}

Key words: Cow dung, sewage sludge, swine waste, poultry manure, waste disposal.

\section{INTRODUCTION}

Sustainable agriculture is fast becoming the focus of the world today. Sustainable agriculture is a method of farming that is not only humane, environmentally friendly and socially ethical, but can sustain itself. In the broadest sense, sustainable agriculture puts back into the earth what it takes out, making a cycle requiring no inputs from

${ }^{*}$ Corresponding author. E-mail: fokenmuo0255@stu.ui.edu.ng.

Author(s) agree that this article remain permanently open access under the terms of the Creative Commons Attribution 
outside. For example, applying fertilizer derived from petroleum products is not sustainable, because the fertilizer was not produced within the agricultural cycle. Composted manure from animals on the farm would be an example of a sustainable fertilizer. Animal wastes may be suitable for amelioration of soils in the humid tropics which are characterized by poor native organic matter and low available nutrients productivity decline overtime when subjected to continous cultivation (Zingore et al., 2003).

In Nigeria, the use of mineral ferilizers is common among farmers, probably for its ability to enhance yield, low cost of application and transportation. However, mineral fertilizers overtime have proved to be scarce, cost intensive, capable of causing pollution and toxicity and incapable of achieving soil conservation needs (Kushwaha and Ochi, 1999). For example, Isherwood (2000) observed initial increase in yield with mineral fertilizer for only few years and followed by decrease in base saturation and acidification. Futhermore, Adeoye et al. (2008) associated decreases in yield, increases in soil acidity, and nutrient imbalance to continous use of mineral ferilizers in tropical soils. Yield declines, pollution vulnerabilities and high cost of mineral fertilizers utilization has reawakened interests in organic wastes especially among the poor smallholder farmers.

The use of organic inputs such as crop residues and manures have great potential for improving soil productivity and crop yield through improvement of the soil physical, chemical, microbiological and nutrient supply (Abbasi et al., 2009). Ofori and Santana (1990) noted that cow dung improved the productivity of soil more than inorganic fertilizer owing to its slow release of nutrients. Organic manures can also increase water infiltration, water holding capacity, water content and aeration (McCauley et al., 2017). Many of the nutrients used by plants are held in organic manure until soil organisms decompose the material and release plant available nutrients. It is evident that a regular addition of organic manure is important as food for not only crops but also micro-organisms, insects, worms and other organisms. Erosion will be reduced and root penetration and tillage operation will be enhanced when the soil is well aggregated (USDA, 2003). Addition of soil organic matter is also an important soil conservation measure that accomplishes soil carbon sequestration and mitigation of climate change (McCauley et al., 2017).

Even though there are many studies dealing with organic manure application in the Abakaliki agro-ecology (Mbah et al., 2004; Mbah and Mbagwu, 2006; Nwite and Alu, 2017), very little is known about their effects on hydromorphic soils and yet such soils are common in the area. The objective of this study was to evaluate the suitability of animal wastes (poultry manure, swine wastes, cow dung, and sewage sludge) on soil physicochemical properties and yield components of maize (Zea mays $L$ ) in a degraded hydromorphic soil in Abakaliki,
Southeastern Nigeria.

\section{MATERIALS AND METHODS}

\section{Description of study area}

The study was carried out at the Teaching and Research Farm of the Faculty of Agriculture and Natural Resources Management, Ebonyi State University, Abakaliki. The area lies within latitude $06^{\circ}$ $4^{1} \mathrm{~N}$ and longitude $08^{\circ} 65^{1} \mathrm{E}$ in the derived savanna zone of Southeastern Nigeria. Rainfall is bimodal; the rainy (April-October) and the dry season (November-March). There is usually a short break in August usually known as "August break". The total mean annual rainfall ranges from $1700 \mathrm{~mm}$ for minimum to 2000 $\mathrm{mm}$ for the maximum, respectively. The annual temperature is between 27 and $31^{\circ} \mathrm{C}$, while relative humidity is between 60 and $80 \%$ during rainy season (Ofomata, 1975). The soil is hydromorphic and belongs to the order ultisol within the Ezzamgbo soil association derived from shale and classified as Typic Haplusult (FDALR, 1986).

\section{Field work}

The study was conducted in a land area of approximately 0.017 ha $\left(13 \times 13 \mathrm{~m}^{2}\right)$. The field was cleared manually of existing vegetation and debris removed. The area was demarcated into plots that measured $2 \times 2 \mathrm{~m}^{2}$ with $0.5 \mathrm{~m}$ space. The Randomized Complete Block Design (RCBD) was used in the experimental design. Animal wastes consisting of poultry manure (PM), swine waste (SW) and cow dung (CD) obtained from the Animal Science section of Ebonyi State University Abakaliki and sewage sludge (SS) were obtained from sewage treatment plant of University of Nigeria, Nsukka. The animal wastes were dried, crushed, analyzed for their respective nutrient components and incorporated into the soil at $20 \mathrm{~cm}$ depth prior to planting. The treatments were 10 tha $^{-1}(4 \mathrm{~kg} / \mathrm{plot})$ of each animal wastes (PM, SW, CD and SS) and a control. They were replicated four times to give a total of twenty experimental plots.

Maize (Zea mays L. var Oba super II) was planted as test crop two weeks after incorporation of treatments. The seed rate was two seed per hole at a spacing of $25 \times 75 \mathrm{~cm}^{2}$ and depth of $5 \mathrm{~cm}$. The seedlings were thinned down to one per hole at two weeks of germination and weeding was bi-weekly.

\section{Agronomic data}

Twelve plants constituting $25 \%$ of plant population per plot were tagged and used for agronomic measurements. Plant height was measured with metric ruler from tallest leaf of a plant to base every two weeks till tasseling. The grain yield was determined by harvesting the cobs after drying of husks. The husks were removed, cobs shelled and maize grains were further dried and grain yield was adjusted to $14 \%$ moisture content.

\section{Laboratory studies}

Selected soil physical and chemical properties were determined after soil samples were collected with core samplers and augers, respectively auger at 0 to $20 \mathrm{~cm}$. Auger samples were composited, dried, ground, seived with $2 \mathrm{~mm}$-mesh seive and labelled at preand post-planting. Bulk density was determined using the method described by Gee and Or (2002). Total porosity determination was done as described by Obi (2000). The method of Stolte (1997) was used to determine saturated hydraulic conductivity (Ks). Gravimetric 
Table 1. Chemical composition of amendments used for the study.

\begin{tabular}{|c|c|c|c|c|c|c|c|c|}
\hline Manure & $\begin{array}{l}\mathrm{pH} \\
(\mathrm{KCl})\end{array}$ & $\begin{array}{l}\text { O.C } \\
(\%)\end{array}$ & TN (\%) & $\underset{\left(\mathrm{mgkg}^{-1}\right)}{\text { Av.P }}$ & $\begin{array}{c}\text { Exch. K } \\
\left(\mathrm{cmol} \mathrm{kg}^{-1}\right)\end{array}$ & $\begin{array}{l}\text { Exch. Ca } \\
\left(\mathrm{cmol} \mathrm{kg}^{-1}\right)\end{array}$ & $\begin{array}{l}\text { Exch. Na } \\
\left(\mathrm{cmol} \mathrm{kg}^{-1}\right)\end{array}$ & $\begin{array}{c}\text { Exch Mg } \\
\left(\mathrm{cmol} \mathrm{kg}^{-1}\right)\end{array}$ \\
\hline PM & 7.5 & 23.0 & 3.67 & 0.4 & 0.55 & 3.27 & 0.33 & 1.52 \\
\hline SW & 7.0 & 20.2 & 2.45 & 0.35 & 0.63 & 3.19 & 0.23 & 1.58 \\
\hline CD & 7.0 & 26.2 & 3.21 & 0.34 & 0.47 & 2.81 & 0.11 & 1.22 \\
\hline SS & 5.91 & 26.2 & 2.76 & 0.16 & 0.48 & 2.91 & 0.28 & 1.39 \\
\hline
\end{tabular}

PM: Poultry manure; SW: Swine wastes; CD: Cow dung; SS: Sewage sludge; O.C: Organic carbon; TN: Total nitrogen; Av. P: Available phosphorus.

moisture content determination was carried out as described by Obi (2000). Particle size distribution (fraction of sand, silt, and clay) was determined using hydrometer method (Gee and Or, 2002) with $\mathrm{NaOH}$ as dispersant. Mean weight diameter was determined using the method described by Obi (2000). Sower (1965) penetrometer and classical techniques were used to determine liquid limit and plastic limit, respectively. Soil pH was determined in $1 \mathrm{M} \mathrm{KCl}$ of $1: 2.5$ soil/water ratio. Organic carbon was determined by the Walkley and Black dichromate oxidation method (Nelson and Sommers, 1982). Organic matter was estimated as organic carbon $\times 1.729$ (Odu et al., 1986). And total nitrogen (TN) by Kjeldahl method (Bremner and Mulvaney, 1982). Available phosphorus by Bray and Kurtz (1945) (Bray II) method. After extraction with $1 \mathrm{~N}$ ammonuim acetate solution, exchangeable $\mathrm{Na}$ and $\mathrm{K}$ were determined by the Flame photometry and $\mathrm{Ca}$ and $\mathrm{Mg}$ by an EDTA titration method. Exchangeable acidity $\left(\mathrm{Al}^{3+}+\mathrm{H}^{+}\right)$was determined by the $\mathrm{KCl}$ displacement method and cation exchange capacity (CEC) was obtained by the ammonuim acetate technique. Percentage base saturation was calculated as total exchangeable bases divided by effective CEC and multiplied by 100. All laboratory analysis was conducted at the Soil Science Research Laboratory, University of Nigeria Nsukka.

\section{Data analysis}

All data collected were analyzed statistically using the analysis of variance technique (ANOVA) and Fishers least significant difference (Steel and Torrie, 1980) was used to separate means and significance was accepted at $5 \%$ probability level.

\section{RESULTS AND DISCUSSION}

\section{Chemical composition of amendments used for the study}

Table 1 shows the chemical composition of the animal wastes used for soil amendment. Total $\mathrm{N}$ was higher $(3.68 \%)$ in poultry manure following the order $\mathrm{PM}>\mathrm{CD}>\mathrm{SS}>\mathrm{SW}$. Sewage sludge was slightly acidic (5.91) while other wastes were neutral to alkaline. Although values of available $P$ were low in the animal wastes based on Landon (1991), it was highest in poultry manure $\left(0.4 \mathrm{mgkg}^{-1}\right)$. The exchangeable $\mathrm{Ca}$ values were $3.72,3.19,2.81$ and $2.91 \mathrm{cmolkg}^{-1}$ for poultry manure, swine waste, cow dung and sewage sludge, respectively and higher than $\mathrm{Mg}, \mathrm{K}$ and $\mathrm{Na}$ values in the wastes.
Exchangeable $\mathrm{Mg}$ and $\mathrm{K}$ were dominant in swine waste (1.58 and $0.63 \mathrm{cmolkg}^{-1}$ ), respectively as compared to other wastes.

\section{Soil properties prior to amendment}

The properties of the soil at the initiation of the study are shown in Table 2. Sand fraction was dominant compared to clay and silt fractions leading to sandy clay loam textural class. The $\mathrm{pH}$ was slightly acidic (5.2) and organic carbon content $(1.8 \%)$ was also low based on rating by Landon (1991). Total nitrogen (0.11\%), available phosphorus $\left(26 \mathrm{mgkg}^{-1}\right)$, cation exchange capacity $\left(8.6 \mathrm{cmolkg}^{-1}\right)$ were rated low (Landon, 1991). Exchangeable calcium and magnesium dominated the exchange sites.

\section{Effect of treatments on soil physical properties}

Table 3 shows the physical properties as influenced by animal wastes. In all treatments, the texture was sandy clay loam which may be attributed to nature of parent materials and high rainfall that could favor washing away and leaching of silt-sized and clay-sized fractions (Igwe et al., 1999; Akamigbo, 2010). The application of animal wastes significantly $(\mathrm{P}<0.05)$ decreased bulk density and increased total porosity. The implication of a lowered bulk density and increased total porosity are ease in root penetration, downward movement of water, more soil water retention, availability for greater water use efficiency by crops and lowered risks of compaction (Ogbodo and Chukwu, 2012; Nwite and Okolo, 2016). Bulk density was lower in SS $\left(1.45 \mathrm{gcm}^{-3}\right)$ amended plots relative to CD $\left(1.51 \mathrm{gcm}^{-3}\right)$, PM $\left(1.54 \mathrm{gcm}^{-3}\right)$ and SW $\left(1.62 \mathrm{gcm}^{-3}\right)$ plots. This reflects the role that the different organic waste decomposition plays in soil loosening. However, saturated hydraulic conductivity obtained in PM amended plots were higher relative to other amendments, following the order $\mathrm{PM}>\mathrm{CD}>\mathrm{SS}>\mathrm{SW}>\mathrm{C}$. $\mathrm{PM}$ relative to the control increased water transmission through the soil by $61.9 \%$. Similarly, gravimetric moisture contents of PM plots were higher relative to the amended and 
Table 2. Pretreatment soil $(0-20 \mathrm{~cm})$ properties.

\begin{tabular}{|c|c|}
\hline Particle size distribution & Value \\
\hline Clay $(\%)$ & 21 \\
\hline Silt (\%) & 20 \\
\hline Sand $(\%)$ & 59 \\
\hline Textural class & SCL \\
\hline Soil pH (KCl) & 5.2 \\
\hline Exch. Ca $\left(\mathrm{cmol} \mathrm{kg}^{-1}\right)$ & 4.1 \\
\hline Exch. $\mathrm{Mg}\left(\mathrm{cmol} \mathrm{kg}^{-1}\right)$ & 2.8 \\
\hline Exch. $\mathrm{Na}\left(\mathrm{cmol} \mathrm{kg}^{-1}\right)$ & 0.03 \\
\hline Exch. $\mathrm{K}\left(\mathrm{cmol} \mathrm{kg}^{-1}\right)$ & 0.1 \\
\hline $\mathrm{CEC}\left(\mathrm{cmol} \mathrm{kg}^{-1}\right)$ & 8.6 \\
\hline Exch. acidity $\left(\mathrm{cmol} \mathrm{kg}^{-1}\right)$ & 1.36 \\
\hline $\mathrm{TN}(\%)$ & 0.11 \\
\hline $\mathrm{OC}(\%)$ & 1.8 \\
\hline Av.P $\left(\mathrm{mgkg}^{-1}\right)$ & 26 \\
\hline
\end{tabular}

Table 3. Physical and properties of the soil as influenced by wastes.

\begin{tabular}{lccccccccccccc}
\hline Treatment & \%Sand & $\%$ Silt & $\%$ Clay & Tex & $\begin{array}{c}\mathbf{B D g} \\
\left.\mathbf{( c m}^{-3}\right)\end{array}$ & TP (\%) & $\begin{array}{c}\text { HC } \\
\left(\mathbf{c m h}^{-1}\right)\end{array}$ & $\begin{array}{c}\text { GMC } \\
(\%)\end{array}$ & $\begin{array}{c}\text { AS } \\
(\%)\end{array}$ & $\begin{array}{c}\text { SA } \\
(\%)\end{array}$ & $\begin{array}{c}\text { MWD } \\
(\%)\end{array}$ & LL & PL \\
\hline Control & 59 & 20 & 21 & SCL & 1.66 & 36.3 & 16 & 13.3 & 10.8 & 2.3 & 1.6 & 19.8 & 15.2 \\
PM & 59 & 23 & 18 & SCL & 1.54 & 42.5 & 41 & 19.0 & 14.7 & 4.7 & 2.5 & 22.5 & 17.7 \\
SW & 58 & 23 & 19 & SCL & 1.62 & 37.8 & 28 & 15.6 & 11.2 & 3.6 & 2.4 & 21.2 & 16.3 \\
CD & 58 & 22 & 20 & SCL & 1.51 & 41.8 & 36 & 14.5 & 13.3 & 3.6 & 2.4 & 20.9 & 18.1 \\
SS & 60 & 21 & 19 & SCL & 1.45 & 41.3 & 30 & 16.8 & 11.1 & 3.4 & 2.4 & 21.5 & 17.0 \\
FLSD (0.05) & NS & NS & NS & - & 0.07 & 3.3 & NS & NS & NS & NS & NS & 22.2 & 17.9 \\
\hline
\end{tabular}

Tex: Soil texture; SCL: Sandy clay loam; BD: Bulk density; TP: Total porosity; HC: Hydraulic conductivity; GMC: Gravimetric moisture content; AS: Aggregate stability; SA: State of aggregate; MWD: Mean weight diameter; LL: Liquid limit; PL: Plastic limit.

unamended plots. There was no significant difference between the control and amended plots in terms of aggregate stability and state of aggregation. Notwithstanding, what seems obvious are slight increase with amendment following the order $\mathrm{PM}>\mathrm{CD}>\mathrm{SW}>\mathrm{SS}>\mathrm{C}$. This corroborates the findings of Wang et al. (2016) who observed that organic matter is an indispensible component in soil aggregation. Similarly, there were no significant differences among the treatments in terms of mean weight diameter. However, PM recorded the highest values $(2.5 \%)$ as compared to other amendments and control $(1.6 \%)$. This indicates that animal wastes enhanced mean weight diameter of soil.

The liquid and plastic limits of amended soil were significantly $(P<0.05)$ increased following amendments. Higher plasticity values were recorded in CD (18.1), PM (17.7), SS (17.0) and SW (16.3) amended plots as compared to the control (15.2). The implication of this is that moisture contents of the soils were improved following the amendments.

\section{Effect of treatments on soil chemical properties}

\section{Soil $\mathrm{pH}$, organic matter, total nitrogen and available phosphorus}

Soil $\mathrm{pH}$ was not significantly $(\mathrm{P}>0.05)$ affected following organic waste amendment as shown in (Table 4). The highest value of 6.1 was obtained in plots amended with poultry manure while the lowest was 5.2 from the control. The increase in $\mathrm{pH}$ due to animal waste amendment have been widely reported in literature (Darmordy et al., 1983; Nwite et al., 2016).

Amendments increased $P$ significantly $(P<0.05)$. The highest value was obtained on poultry manure amended plots $\left(40 \mathrm{mgkg}^{-1}\right)$ as compared to the lowest value $(28$ $\mathrm{mgkg}^{-1}$ ) recorded in the control (Table 4). This agrees 
Table 4. Chemical properties of soil at post Harvest.

\begin{tabular}{|c|c|c|c|c|c|c|c|c|c|c|c|c|}
\hline \multirow{2}{*}{ Treatment } & \multirow{2}{*}{$\begin{array}{l}\mathrm{pH} \\
(\mathrm{KCl})\end{array}$} & \multirow{2}{*}{$\begin{array}{c}\text { Av. P } \\
\left(\mathrm{mgkg}^{-1}\right)\end{array}$} & \multirow{2}{*}{$\begin{array}{l}\text { TN } \\
(\%)\end{array}$} & \multirow{2}{*}{$\begin{array}{l}\text { OM } \\
(\%)\end{array}$} & \multirow{2}{*}{$\begin{array}{l}\mathrm{C}: \mathrm{N} \\
\text { ratio }\end{array}$} & $\mathrm{Ca}$ & $\mathbf{M g}$ & K & $\mathrm{Na}$ & EA & CEC & \multirow{2}{*}{ BS (\%) } \\
\hline & & & & & & \multicolumn{6}{|c|}{$\mathrm{Cmolkg}^{-1}$} & \\
\hline C & 5.2 & 28 & 0.11 & 2.0 & 10 & 4.1 & 2.8 & 0.1 & 0.03 & 1.36 & 8.4 & 80 \\
\hline PM & 6.1 & 40 & 0.13 & 2.3 & 11 & 6.1 & 3.2 & 0.20 & 0.07 & 1.22 & 10.9 & 86 \\
\hline SW & 5.8 & 28 & 0.09 & 2.0 & 13 & 5.1 & 2.8 & 0.13 & 0.06 & 1.30 & 10.2 & 83 \\
\hline CD & 5.9 & 30 & 0.12 & 2.2 & 11 & 4.9 & 2.8 & 0.11 & 0.06 & 1.28 & 9.4 & 83 \\
\hline SS & 5.7 & 36 & 0.11 & 2.1 & 11 & 4.6 & 2.8 & 0.13 & 0.08 & 1.34 & 9.5 & 81 \\
\hline FLSD $(0.05)$ & NS & 7.5 & NS & NS & NS & NS & NS & NS & 0.02 & NS & 1.65 & NS \\
\hline
\end{tabular}

C: Control; PM: poultry manure; SW: swine wastes; CD: cow dung; SS: sewage sludge.

Table 5. Effect of amendments on growth and yield of maize.

\begin{tabular}{lccc}
\hline Treatment & Plant height $\mathbf{( c m})$ & Leaf area index & Grain yield $\left(\right.$ tha $\left.^{-1}\right)$ \\
\hline C & 113.2 & 344 & 0.5 \\
PM & 161.7 & 519 & 1.6 \\
SW & 137.5 & 463 & 1.4 \\
CD & 129.4 & 397 & 0.9 \\
SS & 136.1 & 387 & 1.2 \\
FLSD $(0.05)$ & 20.3 & 154 & 0.2 \\
\hline
\end{tabular}

C: Control; PM: Poultry manure; SW: Swine wastes; CD: Cow dung; SS: Sewage sludge.

with earlier findings by Adeleye and Ayeni (2009) that $P$ content is increased by application of animal wastes.

Total $\mathrm{N}$ exhibited non-significant effect following wastes amendments. Like $P$, the highest value of $0.13 \%$ was obtained in poultry manure amended plots, while the lowest value $(0.11 \%)$ was recorded in the control. There was no significant difference $(P>0.05)$ among the treatments. The increase in total $\mathrm{N}$ of amended plots is similar to the effects observed by Khaliq and Abbasi (2015) and attributed to build up of organic matter in the soil.

There was no significant effect of amendments on soil organic matter. However, plots amended with poultry manure gave the highest values of $2.3 \%$, while $\mathrm{CD}$, SS and SW amended plots gave $2.2 \%, 2.1 \%$ and 2.0 as compared to the control plots $1.9 \%$. This is consistent with reports of Wang et al. (2014) soil organic matter was higher in organic waste amended soils and is dependent on its nature and rate of its decomposition by the microbial community. PM contains both solid and liquid excreta and tends to mineralize faster as compared to wastes from other sources where urine is lost-resulting in high solid excreta (Amanullah et al., 2010). This explains the low C:N ratio of PM amended soils as an indicative faster release of nitrogen.

\section{Exchangeable bases and exchangeable acidity}

Amendments led to an increase in soil CEC especially in
PM plots (Table 4). This implies better supply of nutrients, hence improved fertility in amended plots. The higher values in poultry manure amended plots for $\mathrm{Ca}^{2+}, \mathrm{K}^{+}$and $\mathrm{Mg}^{2+}$ has been observed by other reseachers (Hue and Lucidine, 1999; Adeniyi and Ojeniyi, 2005). There is probably an increase in the amount of $\mathrm{Ca}^{2+}$ derived from $\mathrm{CaCO}_{3}$ due to formation of organic acids. Increased $\mathrm{Ca}^{2+}$ will result in improved soil structure by forming cationic bridges between clay and soil organic matter (David and Dimitrios, 2002). $\mathrm{Mg}^{2+}$ content tended to remain unaltered in all plots excluding the PM amended. The effect of amendments on $\mathrm{Na}$ content was significantly increased. SS amended plots had the highest values for $\mathrm{Na}^{+}$with value of $0.08 \mathrm{cmolkg}^{-1}$, while the control plots had the lowest values. This corroborates early findings (Basta, 1996), that all wastes have high soluble salts in variable quantities and excessive salts in soils (natural or applied) can have detrimental effects on plants growth.

Exchangeable acidities were not significant $(P>0.05)$. Sewage sludge had the highest value of $1.86 \mathrm{cmolkg}^{-1}$. The changes may be due to $\mathrm{Al}^{3+}$ from soil exchange site acted upon by decomposing waste-humus having a weak acid nature (Adediran et al., 2003).

\section{Effect of treatments on growth and yield components}

Plant height was significantly $(\mathrm{P}<0.05)$ increased (Table 5 ) with the application of the amendments. The highest 
result of $161.73 \mathrm{~cm}$ was $43 \%$ higher than the control plots. This was also observed in the leaf area index $(51 \%)$ and yield $(220 \%)$ higher relative to the control. It followed the order $\mathrm{PM}>\mathrm{SW}>\mathrm{SS}>\mathrm{CD}$ for plant height, leaf area index and yield. This agrees with Mbah (2008) and Nwite et al. (2016) who observed that organic manure improves crops yield and is source-dependent.

\section{Conclusion}

The study shows that animal wastes enhanced soil properties and maize yield of hydromorphic ultisols in Abakaliki agro-ecology. The enhancement of soil properties and yield followed the order $\mathrm{PM}>\mathrm{SW}>\mathrm{SS}>\mathrm{CD}$. Poultry manure having low $\mathrm{C}: \mathrm{N}$ ratio had the ability to release faster, hence, performing better than other animal wastes in the short-term. Cow dung, swine wastes and sewage sludge may have greater residual benefits. The application of sewage sludge may be beneficial in certain soil deficiency, but however has toxicity potentials. The application of these wastes at the rate used in this study will lead to restoration of degraded soils, thus ensuring that soil is healthy enough to perform its functions for agricultural sustainability. More studies are however needed using variable quantities and combination of wastes in hydromorphic soils. A long-term study of the wastes in order to bring out a cumulative effect of the amendments will also be a very useful practice.

\section{CONFLICT OF INTERESTS}

The authors have not declared any conflict of interests.

\section{REFERENCES}

Abbasi MK, Mushtaq A, Tahir MM (2009). Cumulative effects of white clover residues on the changes in soil properties, nutrient uptake, growth and yield of maize crop in the sub- humid hilly region of Azad Jamnu and Kashmir Pakistan. African Journal of Biotechnology 8(22):6191.

Adediran JA, Taiwo LB, Sobulo RA (2003). Effect of organic wastes and method of compositing on compost, nutrient maturity, composition of compost and yield of two vegetable crops. Journal of Sustainable Agricultural 22:95-109.

Adeleye EO, Ayeni LS (2009). Effects of soil preparation methods and organic wastes on soil nutrient status and yield of maize (Zea mays) on an alfisol of southwest Nigeria, American-Eurasian Journal of Sustainable Agriculture 3(3):460-467.

Adeniyi ON, Ojeniyi SO (2005). Effect of poultry manure, NPK 15-15-15 and combination of their reduced levels on maize growth and soil chemical properties. Nigerian Journal of Soil Science 15:34-41.

Adeoye GO, Adeoluwa OO, Ojelade M, Sridhar E, Makinde EA, Olowoake AA (2008). Comparative evaluation of organo-mineral fertilizers and mineral fertilizers (NPK) on yield quality of maize (Zea mays (L) Moench). Nigerian Journal of Soil Science 18:132-137.

Akamigbo FOR (2010). Soils: Fundamental Methods of Soil Resource Survey, Classification,Interpretation, Interpretation and Application. Published and printed by University Press Ltd. Bookshop/Bank buiding complex, UNN.

Amanullah MM, Sekar S, Muthukrisnan P (2010). Prospects and potential of poulty manure. Asian Journal of Plant Science 9:172-192.

Basta NT (1996). Soil amendments: Impacts in biotic systems. Soil Science 161(12):885-886.

Bray RH, Kurt LT (1945). Determination of total, organic and available forms of phosphorus in soils. Soil Science 59:39-45.

Bremner JM, Mulvaney CS (1982). Nitrogen total. In Page, A.L.(ed) Methods of soil analysis. No 9. Part 2: Chemical and Microbiological properties, 2nd edn. Am Soc Agron Inc, Madison, WI, USA.

Darmordy RG, Foss JE, Mc itosh M, Wolf DC (1983). Municipal sewage sludge compost amended soils: some spatiotemporal treatment effects. Journal of Environmental Quality 12:2.

David R, Dimitrios P (2002). Diffusion and cation exchange during the reclamation of saline-structured soils. Geoderma 107:271-279.

FDALR (1986). Reconnaissance soils survey of Anambra State. Nigeria Soils report FDALR Kaduna.

Gee GW, Or D (2002). Particle size analysis. In: Dane, J. H. and Topp, G. C. (eds). Methods of soil Analysis. Part 4; physical method. Soil Science Society American 5:255-293.

Hue NV, Licudine DL (1999). Amelioration of subsoil acidity through surface applications of organic manures. Journal. Environmental Quality 28:623-632.

Igwe CA, Akamigbo FOR, Mbagwu JSC (1999). Chemical and mineralogical properties of soils in Southern Nigeria in relation to aggregate stability. Geoderma 92:111-123.

Isherwood KF (2000). Fertilizer use and the Environment, International Fertilizer Industry Association Revised Edition. Paris, France.

Khaliq A, Abbasi MK (2015). Improvement in the physical and chemical characteristics of degraded soils supplemented with organicinorganic amendments in the Himalayan region of Kashmir, Pakistan. Catena 126:209-219.

Kushwaha S, Ochi JE (1991). The economic and social implication of using animal excreta as fertilizer and feedstuff: profitability and environmental protection model. Journal on sustainable Agriculture 14(1):81.

Landon JR (1991). Booker, Tropical soil Manual: A handbook for soil survey and agricultural land evaluation in tropics and subtropics. New York, USA. John Wiley and Sons, Inc. Third Avenue.

Mbah CN (2008). Contribution of Organic amendments to exchangeable Potassium percent and soil nitrate concentration in an Ultisol and their effect on maize (Zea mays $L$ ) grain yield. Agroscience Journal of Tropical Agricultural, Food, Environment and Extention 7(3):206-210.

Mbah CN, Mbagwu JSC (2006). Effect of animal waste on physiochemical properties of a Dystric Leptosol and maize yield in South Eastern Nigeria. Nigeria Journal of soil Science 16(1):96-103.

Mbah CN, Mbagwu JSC, Onyia VN, Anikwe MAN (2004). Effect of application of biofertilizer on soil densification, total porosity, aggregate stability and maize grain yield in dystric leptosol at Abakaliki. Nigeria Journal of Science Tecnology 10:74-85.

McCauley A, Jones C, Olson-Rutz K (2017). Soil pH and organic matter. Nutrient Management Module No. 8, 4449-8. Montana State University/ Extension.

Nelson DW, Sommers LW (1982). Total organic carbon and organic matter. In: Pg (eds) Methods of soil analysis, part 2.Chemical and microbiological properties. Agronomy monograph, No. 7 Madison W, USA.

Nwite JN, Alu MO (2017). Potentials of animal wastes in productivity of a sandy loam in Abakaliki, Southeastern Nigeria. American-Eurasian Journal of Sustainable Agriculture 11(4):1-7.

Nwite JN, Aya FC, Okolo CC (2016). Remediation of Crankcase Oil Contaminated Soil with Different Sources of Manure in Abakaliki, South East, Nigeria. Journal of Bioremediation Biodegration 7:350. DOI:10.4172/2155-6199.1000350.

Nwite JN, Okolo CC (2016) Soil water relations of an Ultisol amended with agro-wastes and its effect on grain yield of maize (Zea Mays L.) in Abakaliki, Southeastern Nigeria. European Journal of Scientific Research 141(2):126-140.

Obi ME (2000). Soil Physics. A compendium of lectures. Nsukka, Atlantic Publishers.

Odu CT, Babalola IO, Udo EJ, Ogunkunle AO, Bakare TA, Adeoye GO (1986). Laboratory manual for agronomic studies in soil plant and microbiology. Department of Agronomy, University of Ibadan, Nigeria P 83. 
Ofori CS, Santana R (1990). Fertilizer their potential and use in Africa agriculture in organic matter management and tillage in sub-humid Africa- IIBSRAM PROC 10:213-219.

Ofomata GEK (1975) Nigeria in maps, Eastern states. In G.E.K. Ofomata E.d Ethiopia pub house, Benin City Pp. 45-46.

Ogbodo EN, Chukwu GO (2012). Soil fertility evaluation of selected Aquic Haplustalfs in Ebonyi State, Southeast Nigeria. Nigeria Journal of Soil Science 22(1)97-102.

Sower GF (1965) Consistency method of soil analysis, part $11^{\text {st }}($ Ed) in: C.A Black et al American Society of Agronomy, Madison, Ulis Cousin pp. 391-399.

Steel RGD, Torrie JH (1980). Principles and procedures of statistics. A biometric approach. 2nd ed. McGraw Hill, Book Co. Inc. New York pp. 1-3.

Stolte J (1997). Manual of soil physical measurement. Version 3 Wageningen, DLO Winand Staring Centre for Integrated Land. Soil and Water Research, Technical Document P 37.

United State Development Agency (USDA) (2003). Organic matter management and soil conservation into agricultural service information bulletin No 229 .
Wang L, Sun X, Li S, Zhang T, Zhang W, Zhai P (2014). Application of organic amendments to a coastal saline soil in North China: effects on soil physical and chemical properties and tree growth. PLoS ONE 9(2):e89185. doi:10.1371/journal.pone.0089185.

Wang J, Yang W, Bi Y, Li Z, Ma R (2016). Estimating the influence of related soil properties on macro- and micro-aggregate stability in ultisols of south-central China. Catena 137:545-553.

Zingore S, Mafongoya P, Myamagafota P, Giller KF (2003). Nitrogen mineralization and maize yield following application of tree prunning to a sandy soil in Zimbabwe. Agroforestry system 57:119-211. 